RESEARCH Note

\title{
Microplastic ingestion and feeding ecology in three intertidal mollusk species from Lima, Peru
}

\author{
Ingestión de microplásticos y ecología alimentaria en tres especies de moluscos \\ intermareales de Lima, Perú
}

\section{Gabriel Enrique De-la-Torre ${ }^{1 *}$, Diego Marcelo Apaza-Vargas ${ }^{1}$ and Luis Santillán $^{1,2}$}

\author{
${ }^{1}$ Universidad San Ignacio de Loyola, Av. La Fontana 501, Lima 12, Perú \\ ${ }^{2}$ Peruvian Centre for Cetacean Research (CEPEC), Museo de los Delfines, Lima 20, Perú \\ *Corresponding author: gabriel.delatorre@usil.pe, gabriel.e.dltp@gmail.com
}

\begin{abstract}
Microplastics $(<5 \mathrm{~mm})$ are ubiquitous contaminants in the marine environment. The aims of the present study were to report the incidence of microplastic pollution in three mollusk species from the coast of Lima and to investigate the relationship between microplastic ingestion and feeding ecology. Specimens of three mollusk species Semimytilus algosus, Tegula atra and Chiton granosus were sampled from the intertidal rocky zone. For microplastic isolation, soft tissues were digested in $10 \% \mathrm{KOH}$, vacuum filtrated and analyzed under a microscope. Rigorous contamination prevention measures were taken into account. $C$. granosus was the most contaminated mollusk $\left(6.92 \pm 2.13\right.$ particles $\left.\mathrm{g}^{-1}\right)$. Red fibers were the overall most abundant microplastic. The feeding behavior of $T$. atra promotes microplastic exposure to $C$. granosus. More research is needed to fully understand the microplastic effects on mollusk species.
\end{abstract}

Key words: Microplastic, mollusk, plastic debris, Peru

\section{INTRODUCTION}

In 2017, annual global production of plastic reached close to 350 million tons (PlasticsEurope 2018) ${ }^{1}$, demonstrating its importance within our lifestyle. Plastics are synthetic organic polymers derived from petroleum that are versatile, lightweight, strong and durable, thus making ideally suited for a variety of applications and highly resistant to degradation (Derraik 2002, Rios et al. 2007, Andrady 2011). Plastics are a global issue and is perceived as one of the most severe forms of pollution in shorelines, oceans and freshwater bodies (Li et al. 2016a).

Whilst there is not a scientific standard, microplastics have been attributed with different size-ranges (Cole et al. 2011). The present study refers to microplastics as anthropogenic particles ranging below $5 \mathrm{~mm}$ in diameter (Barnes et al. 2009). These are subdivided in two categories: primary microplastics, which are plastics that are manufactured to be of microscopic size (Cole et al. 2011) such as plastic scrubbers in skin cleaners as reported by Lei et al. (2017) and secondary microplastics, as consequence of the breakdown of larger plastic debris by degradation (Cole et al. 2011). The distribution of plastic debris in the ocean is irregular due to local wind and current conditions; it is apparent that microplastics have become both wide-spread and ubiquitous (Barnes et al. 2009, Cole et al. 2011). Due to their size, microplastics are prone to be ingested by marine biota; in addition to potential adverse effects from ingestion, toxic responses could also result from inherent contaminants leaching from the microplastics and extraneous hydrophobic pollutants adhered to the microplastics (Cole et al. 2011). Moreover, it is suggested that microplastics can be transferred within different food webs (De-la-Torre 2020), raising concerns regarding microplastic bioaccumulation and biomagnification in marine biota (Barboza et al. 2018).

Filter feeders are between the most vulnerable species to microplastic pollution in the marine environment. Bivalves are widely used as biomonitors in marine ecosystems due to their global distribution, accessibility and high tolerance to salinity (Li et al. 2016b). More specifically, mussels have been previously proposed by Li et al. (2019) as a global bioindicator of microplastic pollution. On the other hand, Polyplacophora and Gastropoda species are poorly studied. Rock grazers and detritivore species, like most marine chitons and snails, are also exposed to microplastics from the marine environment, therefore compromising their survival. Little is known about the relationship between microplastic ingestion and feeding ecology of coastal marine mollusks.

There is still scarce information assessing microplastic pollution in the marine environments of Peru. Thus, the objectives of the present study were (1) to report the incidence and characteristics of microplastic pollution in three mollusks from the intertidal rocky zone from Lima, Peru; and (2) investigate the relationship between microplastic content and feeding behavior in three different mollusk species. 


\section{Materials AND MEthods}

Specimens of three mollusk species were collected from the intertidal rocky zone in Los Yuyos $\left(12^{\circ} 09^{\prime} 11.7^{\prime \prime} \mathrm{S}\right.$; $\left.77^{\circ} 01^{\prime} 31.5^{\prime \prime} \mathrm{W}\right)$ and Las Sombrillas (12 ${ }^{\circ} 09^{\prime} 25.4$ "S; $\left.77^{\circ} 01^{\prime} 35.1^{\prime \prime} \mathrm{W}\right)$ beaches of Lima, Peru, both highly polluted with marine litter (De-la-Torre \& Laura 2019) and microplastics (De-la-Torre et al. 2020). Importantly, these sites are considered unhealthy by local authorities due to anthropogenic pollution. Two sampling points were considered in the intertidal rocky shore of these locations. Specimens of filter feeder Semimytilus algosus $(\mathrm{n}=45)$, and grazers Chiton granosus $(\mathrm{n}=15)$ and Tegula atra $(\mathrm{n}=$ 15) were collected in three sampling campaigns throughout February 2019. Collected specimens were placed in glass containers and stored at $-20{ }^{\circ} \mathrm{C}$ until further laboratory analysis.

The length and wet weight of each mollusk were recorded (Table 1). The soft tissues were extracted by dissecting the mollusks using a scalpel. For S. algosus three specimens were pooled. Then, the soft organic material was digested using Protocol 1b as described by Dehaut et al. (2016) with minor changes. In brief, the soft tissues were submerged in $15 \mathrm{ml}$ of $10 \%(\mathrm{w} / \mathrm{v})$ potassium hydroxide $(\mathrm{KOH})$ in Pyrex screw cab test tubes and incubated over night at 60 ${ }^{\circ} \mathrm{C}$. Digestion was followed by vacuum filtration of the supernatant solution through $20 \mu \mathrm{m}$ pore glass fiber filter paper (Whatman PLC 122 United Kingdom). Filter papers were placed in closed glass petri dishes until further analysis.

Optical identification of microplastics was performed using an optical microscope (Krüss MBL2000) under 10$40 \times$ magnification. To avoid false positives and negatives, microplastics were identified according to their physical characteristics, structure, color, morphology, and such (Desforges et al. 2014). Glass fibers were identified and discarded according to its description by Davidson \& Dudas (2016). Microplastic abundance, type (fibers, beads, fragments and films) and color were recorded. All confirmed microplastics were photographed.

Following Hernandez-Milian et al. (2019), the term microplastic was used for anthropogenic particles smaller than $5 \mathrm{~mm}$. The aim of this study was to investigate the relationship between anthropogenic particles content and feeding behavior in three mollusk types, therefore polymer identification by infrared spectrometry analysis was not necessary (Lusher et al. 2014, Hernandez-Milian et al. 2019).

To reduce external contamination, the protocol described by Dioses-Salinas et al. (2020) was followed. In brief, cotton lab coats and latex gloves were worn at all times. All the equipment was rinsed with distilled water and all surfaces
Table 1. Shell length and soft tissue wet weight of three rocky intertidal mollusks from Lima, Peru / Longitud de la concha y peso húmedo de los tejidos blandos de tres moluscos del intermareal rocoso en Lima, Perú

\begin{tabular}{lccc}
\hline \multicolumn{1}{c}{ Species } & Number & $\begin{array}{c}\text { Shell length } \\
(\mathrm{cm})\end{array}$ & $\begin{array}{c}\text { Soft tissue wet } \\
\text { weight }(\mathrm{g})\end{array}$ \\
\hline Semimytilus algosus & 45 & $3.90 \pm 0.05$ & $1.21 \pm 0.02$ \\
Chiton granosus & 15 & $3.84 \pm 0.08$ & $1.28 \pm 0.10$ \\
Tegula atra & 15 & $2.22 \pm 0.05$ & $1.75 \pm 0.09$ \\
\hline
\end{tabular}

were wiped clean. Glass and metal materials were used and plastic materials were avoided completely. Sampled organisms were stored in glass containers. For every batch of organisms treated, a blank control (distilled water) and a $10 \% \mathrm{KOH}$ blank were prepared, vacuum filtrated and analyzed under the microscope.

Results were expressed in particles ind.-.$^{-1}$ and particles $\mathrm{g}^{-1}$ (wet weight) \pm standard error of the mean (SEM). Kolmogorov-Smirnov and Shapiro-Wilk tests invalidated the normal distribution of the data, thus non-parametric tests were used. Kruskal-Wallis test followed by Dunn's multiple comparisons test were conducted to compare microplastic abundance between mollusk species. Significance level was set to 0.05 for all the analyses. Statistical analysis was performed and graphs were created using GraphPad Prism (version 7.0 for Windows).

\section{RESULTS AND DISCUSSION}

All three mollusk species were contaminated with microplastics. Distilled water and $10 \% \mathrm{KOH}$ blanks had a mean microplastic concentration of $0.50 \pm 0.22$ particles blank $^{-1}$, similar to Li et al. (2015). All particles in the blanks were identified as microfibers.

The overall abundance in the three mollusk species was $3.79 \pm 0.85$ particles ind. ${ }^{-1}$ and $3.15 \pm 0.81$ particles $\mathrm{g}^{-1}$. $C$. granosus showed to be the most contaminated mollusk, containing $6.92 \pm 2.13$ particles $\mathrm{g}^{-1}$, followed by $S$. algosus $\left(1.65 \pm 0.22\right.$ particles $\left.\mathrm{g}^{-1}\right)$ and T. atra $(0.88 \pm 0.20$ particles $\left.\mathrm{g}^{-1}\right)$. Kruskal-Wallis test $(P<0.01)$ indicated significant differences between microplastic concentration in the three mollusk species in terms of particles ind.$^{-1}$ and particles $\mathrm{g}^{-1}$. Dunn's multiple comparison post-hoc test indicated in both particles ind. ${ }^{-1}$ and particles $\mathrm{g}^{-1}$ that microplastic concentration in S. algosus and T. atra were not significantly different $(P>0.99)$, while $C$. granosus differed significantly $(P<0.05)$ from both $S$. algosus and T. atra (Fig. 1a). Fibers were the most common microplastics in all three species, followed by fragments, spheres and films (Table 2) (Fig. 1c). 
Table 2. Abundance percentage of microplastic types in three species of intertidal mollusks. Fibers derive from textile shedding, fragments form from the breakdown of larger solid plastics, spheres are manufactured micro-sized and are found in cosmetics, and films derive from packaging or plastic bags / Porcentaje de abundancia de cada tipo de microplásticos en tres especies de moluscos intermareales. Las fibras se desprenden de los textiles, los fragmentos de la ruptura de plásticos sólidos más grandes, las esferas son fabricadas de tamaño microscópico y se encuentran en cosméticos y los films derivan de plástico de embalaje o bolsas

\begin{tabular}{lcccc}
\hline \multicolumn{1}{c}{ Species } & $\begin{array}{c}\text { Fiber } \\
(\%)\end{array}$ & $\begin{array}{c}\text { Fragment } \\
(\%)\end{array}$ & $\begin{array}{c}\text { Sphere } \\
(\%)\end{array}$ & $\begin{array}{c}\text { Film } \\
(\%)\end{array}$ \\
\hline Semimytilus algosus & $60.23 \%$ & $32.95 \%$ & $4.55 \%$ & $2.27 \%$ \\
Chiton granosus & $84.87 \%$ & $15.13 \%$ & $0 \%$ & $0 \%$ \\
Tegula atra & $59.09 \%$ & $40.91 \%$ & $0 \%$ & $0 \%$ \\
\hline
\end{tabular}

Spheres and films were not observed in C. granosus and T. atra. Regarding microplastic color, red microplastics were dominant in C. granosus (46.22\%) and T. atra (50\%), while blue microplastics were dominant in S. algosus (35.23\%) (Fig. 1b).

a)

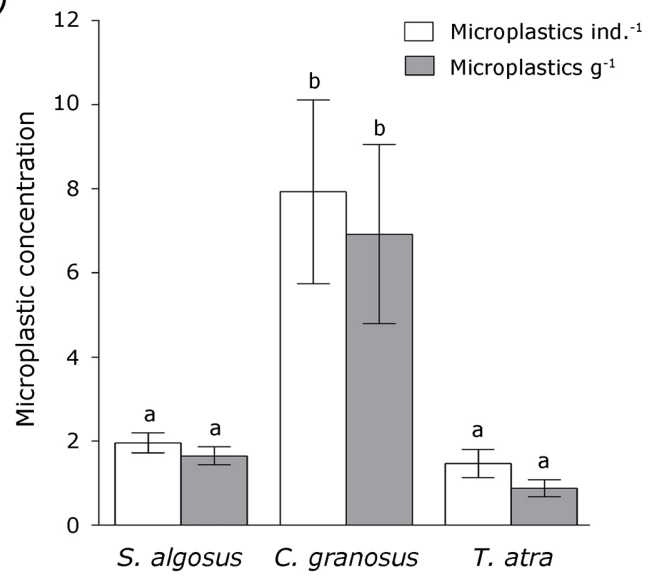

Microplastic content in C. granosus was similar to Naji et al. (2018) in Amiantis umbonella (6.9 \pm 2.3 particles ind. $\left.{ }^{-1}\right)$ and Amiantis purpuratus $\left(6.1 \pm 1.8\right.$ particles ind. $\left.{ }^{-1}\right)$ specimens from the Persian Gulf. Similar to our results, Li et al. (2015) reported low microplastic concentrations in Mytilus edulis (2.2 particles $\mathrm{g}^{-1}$ ) from China. Research regarding microplastic ingestion by mollusks is still scarce, thus more research is needed.

As wastewater treatment plants (WWTPs) play an important role in releasing microplastic to the marine environment (Sun et al. 2019), the proximity to the discharge point of La Chira, the largest WWTP in Lima, and active fishing activity may be the cause of abundant fiber particles, as fibers shed from laundering clothes (Browne et al. 2011) and degrade from fishing nets. Li et al. (2015) reported black, red and blue colors as the most frequent in bivalves, similar to Ding et al. (2018), indicating black, blue and green as the most popular. Indeed, our results have a similar approach to the color proportion reported in literature.

C)
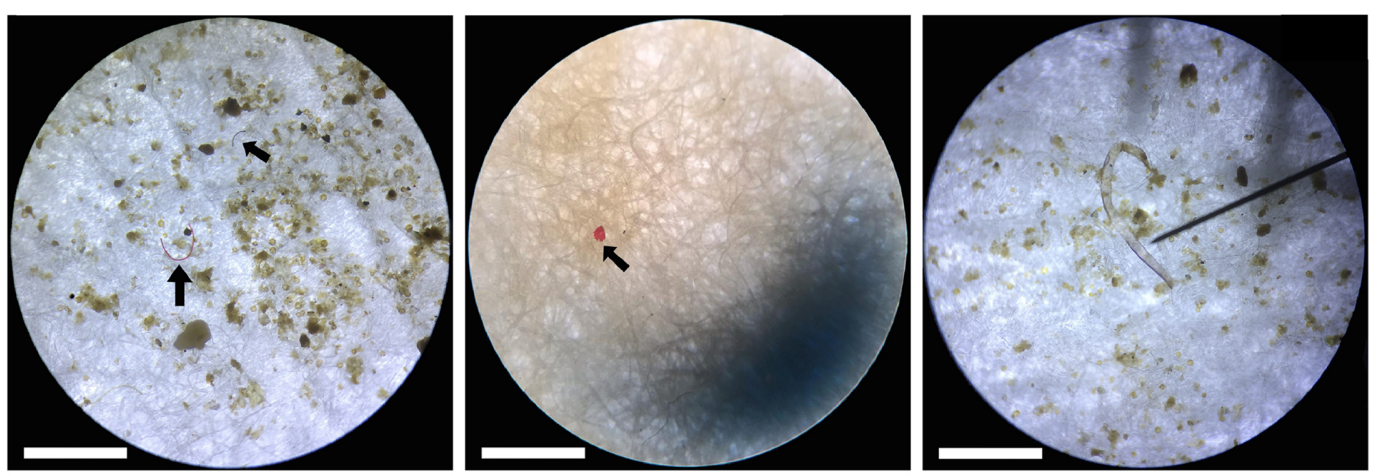

Figure 1. a) Microplastic concentrations in three intertidal mollusks from Lima, Peru. Error bars indicate SEM. Letters indicate significant differences; b) Composition of different microplastic colors in three rocky intertidal mollusks from Lima, Peru; c) Photographs of three different microplastics (fibers, fragment and film) extracted from molluskan soft tissue. Scale bar indicates $1 \mathrm{~mm}$. Arrows point the identified microplastic/a) Concentración de microplásticos en tres moluscos del intermareal rocoso en Lima, Perú. Las barras de error indican el error estándar de la media. Las letras indican diferencias significativas; b) Composición de diferentes colores de microplásticos en tres moluscos del intermareal rocoso en Lima, Perú; c) Fotografías de tres microplásticos diferentes (fibras, fragmento y film) extraídos de tejidos blandos de moluscos. La barra de escala indica $1 \mathrm{~mm}$. Las flechas señalan los microplásticos identificados 
In both sampling sites, T. atra specimens were found gliding on the surfaces of rocks and big boulders, while C. granosus inhabiting rock crevices. In several occasions both species were located close to each other or resting on the same boulder. On the contrary, $S$. algosus beds were separated by a few meters, colonizing isolated boulders partially buried in the sediment. C. granosus carry out foraging excursions of about $30-40 \mathrm{~cm}$ twice a day and has a tendency to come back into the rock crevices (Aguilera \& Navarrete 2007), thus indicating a direct interaction with $T$. atra individuals. In situ observations determined that the foraging excursions by the sampled C. granosus specimens were carried out across T. atra gliding trace. Previous research (Gutow et al. 2019) revealed that gastropod pedal mucus retains suspended microplastics and foraging on the contaminated mucus promotes microplastic ingestion by marine grazers. Consequently, Polyplacophora and Gastropoda species from the intertidal rocky shore are exposed to microplastics adhered to pedal mucus. However, S. algosus are not subject to species interactions that may promote microplastic exposure. Once ingested, microplastics in marine mollusks are expected to scale along the food chain. De-la-Torre et al. (2019) suggested that high microplastic abundance in the gastrointestinal tracts of carnivorous fish were due to ingestion of contaminated mollusks.

It has been observed in other marine gastropod species (Littorina littorea) with similar feeding activity to $T$. atra that ingested microplastics through contaminated seaweed were mostly released through the feces and do not bioaccumulate rapidly (Gutow et al. 2015). This suggests T. atra may self-depurate from ingested microplastics and provoke a higher microplastic exposure to C. granosus when foraging, thus explaining why results indicated C. granosus as the most contaminated mollusk (Fig. 1a) and the microplastic type (Table 2) and color proportion similarities (Fig. 1b).

In the present study, the first evidence of microplastic ingestion by mollusks from Peru was presented. Microplastic concentrations in three mollusk species and physical characteristics of ingested microplastics were determined. The relationship between feeding ecology and microplastic exposure in three mollusk species was investigated and discussed. Further research must focus on determining the toxicity, chronical effects and physical impacts of microplastics in mollusks.

\section{ACKnOWLedgements}

The authors would like to give special thanks to Sandra Casimiro, Head of Research and Teaching Laboratories, for allowing the research to be conducted in the research laboratories of San Ignacio de Loyola University and providing the authors with high grade reagents and proper instruments. The authors are also thankful to the anonymous peer reviewers for their useful suggestions and constructive comments.

\section{LITERATURE CITED}

Aguilera MA \& SA Navarrete. 2007. Effects of Chiton granosus (Frembly, 1827) and other molluscan grazers on algal succession in wave exposed mid-intertidal rocky shores of central Chile. Journal of Experimental Marine Biology and Ecology 349(1): 84-98. <https://doi. org/10.1016/j.jembe.2007.05.002>

Andrady AL. 2011. Microplastics in the marine environment. Marine Pollution Bulletin 62(8): 1596-1605.

Barboza LGA, AD Vethaak, BRBO Lavorante, A Lundebye \& L Guilhermino. 2018. Marine microplastic debris: An emerging issue for food security, food safety and human health. Marine Pollution Bulletin 133: 336-348.

Barnes DKA, F Galgani, RC Thompson \& M Barlaz. 2009. Accumulation and fragmentation of plastic debris in global environments. Philosophical Transactions of the Royal Society B: Biological Sciences 27(1526): 1985-1998.

Cole M, P Lindeque, C Halsband \& TS Galloway. 2011. Microplastics as contaminants in the marine environment: A review. Marine Pollution Bulletin 62(12): 2588-2597.

Davidson K \& SE Dudas. 2016. Microplastic ingestion by wild and cultured manila clams (Venerupis philippinarum) from Baynes Sound, British Columbia. Archives of Environmental Contamination and Toxicology 71(2): $147-156$

De-la-Torre GE. 2020. Microplastics: an emerging threat to food security and human health. Journal of Food Science and Technology. 57(5): 1601-1608

De-la-Torre GE \& RP Laura. 2019. Composición, características físicas y generación per cápita de los residuos sólidos en la playa Las Sombrillas, Lima. Manglar 16(1): 39-44.

De-la-Torre GE, DC Dioses-Salinas, BL Pérez-Baca \& L Santillán. 2019. Microplastic abundance in three commercial fish from the coast of Lima, Peru. Brazilian Journal of Natural Sciences 2(3): 171-177.

De-la-Torre GE, DC Dioses-Salinas, JM Castro, R Antay, NY Fernández, D Espinoza-Morriberón \& M Saldaña-Serrano. 2020. Abundance and distribution of microplastics on sandy beaches of Lima, Peru. Marine Pollution Bulletin 151: 110877. <https://doi.org/10.1016/j. marpolbul.2019.110877> 
Dehaut A, A Cassone, L Frère, L Hermabessiere, C Himber, E Rinnert, G Rivière, C Lambert, P Soudant, A Huvet, G Duflos \& I Paul-Pont. 2016. Microplastics in seafood: Benchmark protocol for their extraction and characterization. Environmental Pollution 215: 223-233.

Derraik JGB. 2002. The pollution of the marine environment by plastic debris: a review. Marine Pollution Bulletin 44(9): 842-852.

Desforges JPW, M Galbraith, N Dangerfield \& PS Ross. 2014. Widespread distribution of microplastics in subsurface seawater in the NE Pacific Ocean. Marine Pollution Bulletin 79(9): 94-99.

Ding J, S Zhang, RM Razanajatovo, H Zou \& W Zhu. 2018. Accumulation, tissue distribution, and biochemical effects of polystyrene microplastics in the freshwater fish red tilapia (Oreochromis niloticus). Environmental Pollution 238: 1-9. <https://doi.org/10.1016/j.envpol.2018.03.001>

Dioses-Salinas DC, CI Pizarro-Ortega \& GE De-la-Torre. 2020. A methodological approach of the current literature on microplastic contamination in terrestrial environments: Current knowledge and baseline considerations. Science of The Total Environment 730: 139164. <https://doi. org/10.1016/j.scitotenv.2020.139164>

Gutow L, A Eckerlebe, L Giménez \& R Saborowski. 2015. Experimental evaluation of seaweeds as a vector for microplastics into marine food webs. Environmental Science, \& Technology 50(2): 915-923.

Gutow L, K Bartl, R Saborowski \& J Beermann. 2019. Gastropod pedal mucus retains microplastics and promotes the uptake of particles by marine periwinkles. Environmental Pollution 246: 688-696.

Hernandez-Milian G, A Lusher, S MacGabban \& E Rogan. 2019. Microplastics in grey seal (Halichoerus grypus) intestines: Are they associated with parasite aggregations? Marine Pollution Bulletin 146: 349-354.
Lei K, F Qiao, Q Liu, Z Wei, H Qi, S Cui, X Yue, Y Deng \& LAn. 2017. Microplastics releasing from personal care and cosmetic products in China. Marine Pollution Bulletin 123(1-2): 122-126.

Li J, D Yang, L Li, K Jabeen \& H Shi. 2015. Microplastics in commercial bivalves from China. Environmental Pollution 207: 190-195.

Li WC, HF Tse \& L Fok. 2016a. Plastic waste in the marine environment: A review of sources, occurrence and effects. Science of the Total Environment 566/567: 333-349.

Li J, X Qu, L Su, W Zhang, D Yang, P Kolandhasamy, D Li \& H Shi. 2016b. Microplastics in mussels along the coastal waters of China. Environmental Pollution 214: 177-184.

Li J, AL Lusher, JM Rotchell, S Deudero, A Turra, ILN Brate, C Sun, MS Hossain, Q Li, P Kolandhasamy \& H Shi. 2019. Using mussel as a global bioindicator of coastal microplastic pollution. Environmental Pollution 244: 522-533.

Lusher AL, A Burke, I O'Connor \& R Officer. 2014. Microplastic pollution in the Northeast Atlantic Ocean: Validated and opportunistic sampling. Marine Pollution Bulletin 88(1-2): 325-333.

Naji A, M Nuri \& AD Vethaak. 2018. Microplastics contamination in molluscs from the northern part of the Persian Gulf. Environmental Pollution 235: 113-120.

Rios LM, C Moore \& PR Jones. 2007. Persistent organic pollutants carried by synthetic polymers in the ocean environment. Marine Pollution Bulletin 54(8): 1230-1237.

Sun J, X Dai, Q Wang, MCM van Loosdrecht \& B Ni. 2019. Microplastics in wastewater treatment plants: Detection, occurrence and removal. Marine Pollution Bulletin 152: 21-37. 